\title{
Pengaruh Kualitas Pelayanan dan Kepuasan Nasabah Terhadap Switching Intention pada Nasabah Bank Panin Kota Sungai Penuh Periode Tahun 2016
}

\author{
Edia Satria \\ Sekolah Tinggi Ilmu Ekonomi Sakti Alam Kerinci \\ Correspondence email: ediasatria@yahoo.co.id
}

\begin{abstract}
Abstrack. This study aimed to find out 1) what is the influence of service quality to switching intention to Bank Panin customers of Sungai Penuh City? 2) the extent to which the effect of customer satisfaction on switching intention on customer Bank Panin Sungai Penuh City? 3) the extent of the influence of service quality to switching intention either directly or indirectly? 4) the extent to which customer satisfaction satisfaction of customer service to switching intention either directly or indirectly? The population in this research is Bank Panin customer period 2016. hence got sample size 51 customer with accidental sampling, sampling technique. The data analysis tool used is path analysis at alpha level of 0.05. Based on the result of research indicate that service quality has no significant effect to switching intention, customer satisfaction has positive and significant effect to switching intention.
\end{abstract}

Keywords: service quality, customer satisfaction and switching intention

\section{PENDAHULUAN}

Switching intention adalah kecenderungan perilaku konsumen yang berhubungan dengan proses beralih dari satu jasa ke penyedia jasa lainnya. Niat beralih erat kaitannya dengan konsep keinginan untuk berperilaku, yang dibangun atas sikap konsumen terhadap objek dan perilaku sebelumnya. Nasabah dapat melakukan Switching intention yang diakibatkan oleh nasabah yang tidak merasa puas terhadap pelayanan yang diberikan oleh Bank Panin Kota Sungai penuh. Kualitas jasa atau pelayanan dipengaruhi oleh dua perubah, yaitu jasa atau pelayanan yang dirasakan dan jasa yang diharapkan. Bila saja yang dirasakan lebih kecil daripada yang diharapkan, para pelanggan menjadi tidak tertarik pada penyedia jasa atau pelayanan yang bersangkutan sedangkan bila yang terjadi adalah sebaliknya ada kemungkinan pelanggan akan setia kepada penyedia jasa atau layanan tersebut. Kotler and Keller (2007) memandang kepuasan konsumen terhadap suatu jasa adalah perbandingan antara persepsinya terhadap jasa yang diterima dengan harapannya sebelum menggunakan jasa tersebut, apabila harapannya terlampaui berarti jasa tersebut telah memberikan suatu kualitas yang luar biasa, dan juga akan menimbulkan kepuasan yang sangat tinggi. Sebaliknya ketidakpuasan terjadi apabila harapan itu tidak memenuhi apa yang diinginkan atau perusahaan tersebut gagal melayani konsumennya. Apabila harapannya sama dengan apa yang diperoleh atau yang diharapkan berarti konsumen mendapat kepuasan.

\section{Switching intention}

Switching intention atau niat beralih pada konsumen yang dilakukan akibat dari ketidakpuasan layanan yang dirasakan konsumen dapat menyebabkan terjadinya negative word-of mouth serta dapat menimbulkan tanggapan dari pihak ketiga. Switching intention merupakan keinginan konsumen untuk berhenti menggunakan layanan jasa yang sedang dipakainya dan berganti ke layanan jasa yang lainnya. Nelloh dan Liam (2011) menyatakan bahwa switching intention sebagai kemungkinan konsumen akan melakukan perpindahan layanan jasa yang sedang dipakainya ke layanan jasa yang lainnya. Menurut Clemes, Gan \& Zhang (2007) menemukan pengaruh switching inention adalah sebagai berikut:

a. Harga adalah suatu nilai tukar yang bisa disamakan dengan uang atau barang lain untuk manfaat yang diperoleh dari suatu barang atau jasa bagi seseorang atau kelompok pada waktu tertentu dan tempat tertentu.

b. Reputasi atau citra adalah suatu gambaran yang ada di dalam benak sesorang. Citra saat berubah menjadi buruk atau negatif, apabila kemudian ternyata tidak didukung oleh kemampuan atau keadaan yang sebenarnya.

c. Respon terhadap pelyanan yang gagal adalah presepsi yang dimiliki oleh pelanggan terhadap satu atau 
lebih jenis pelayanan yang tidak memenuhi harapan mereka.

d. Kualitas pelayanan adalah upaya pemenuhan kebutuhan yang dibarengi dengan keinginan konsumen serta keteapan cara penyampaiannya agar dapat memenuhi harapan dan kepuasan pelanggan.

e. Kepuasan konsumen adalah konsumen dapat dikatakan puas apabila nilai yang diberikan sesuai dengan harapan konsumen.

f. Produk layanan adalah suatu barang atau jasa yang ditawarkan kepada konsumen yang dapat memberikan kepuasan dan maanfaat bagi konsumen.

g. Komitmen pelanggan adalah sebagai suau keadaan dimana seseorang pelanggan memihak terhadap suatu barang atau jasa tertentu serta tujuan-tujuan dan keinginannya mempertahankan hal tersebut.

h. Karateristik demografi adalah ciri yang menggambarkan perbedaan masyarakat berdasarkan usia, jenis kelamin, pekerjaan, pendidikan, agama dll.

i. Kompetisi keefektifan iklan (promosi) adalah upaya untuk memberitahukan atau menawarkan produk atau jasa pada masyarakat luas dengan tujuan menarik calon konsumen untuk membeli atau menggunakan produk atau jasa.

j. Keterpaksaan

\section{Kualitas Pelayanan}

Kualitas layanan yang baik dalam suatu perusahaan akan dapat memberikan rasa puas terhadap pelanggan. Kualitas layanan merupakan perbedaan antara harapan pelanggan dengan pelayanan yang diberikan oleh perusahaan. Kualitas pelayanan sebagai sikap konsumen yang berkaitan dengan hasil dari perbandingan antara harapan dari layanan dengan persepsinya terhadap kinerja aktual. Kualitas layanan merupakan segala kegiatan yang bertujuan untuk memenuhi kebutuhan dan keinginan pelanggan agar sesuai harapan mereka. Terdapat lima dimensi servqual yakni sebagai berikut:

a. Tangibles (bukti fisik) yaitu kemampuan suatu perusahaan dalam menunjukkan eksistensinya kepada pihak eksternal

b. Reliability (keandalan) yaitu kemampuan perusahaan untuk memberikan layanan sesuai yang disajikan secara akurat dan terpercaya

c. Responsiveness (ketanggapan) yaitu suatu kemampuan untuk membantu dan memberikan pelayanan yang cepat dan tepat pada pelanggan, dengan penyampaian informasi yang jelas

d. Assurance (jaminan) yaitu pengetahuan, kesopanan, dan kemampuan para pegawai perusahaan untuk menumbuhkan rasa percaya para pelanggan kepada konsumen

e. Empathy yaitu memberikan perhatian yang tulus dan besifat individual atau pribadi yang diberikan kepada para pelangan dengan berupaya memahami kenginan konsumen.

\section{Kepuasanan Nasabah}

Kotler and Keller (2007) memandang kepuasan konsumen terhadap suatu jasa adalah perbandingan antara persepsinya terhadap jasa yang diterima dengan harapannya sebelum menggunakan jasa tersebut, apabila harapannya terlampaui berarti jasa tersebut telah memberikan suatu kualitas yang luar biasa, dan juga akan menimbulka kepuasan yang sangat tinggi. Sebaliknya ketidakpuasan terjadi apabila harapan itu tidak memenuhi apa yang diinginkan atau perusahaan tersebut gagal melayani konsumennya. Apabila harapannya sama dengan apa yang diperoleh atau yang diharapkan berarti konsumen mendapat kepuasan. Kotler (2007) mengemukakan kepuasan pelanggan sebagai perbandingan antara layanan yang diharapkan (expectation) dan kinerja (perfomance).

Kepuasan adalah suatu jenis dari langkah perjalanan suatu pengalaman yang menyenangkan menjadi tidak puas karena kesenangan, bukan seperti kesenangan yang dikira atau diharapkan, maka kepuasan/ketidakpuasan bukan suatu emosi, tetapi evaluasi dari suatu emosi. Kotler (2007) mengatakan kepuasan pelanggan adalah tingkat perasaan seseorang setelah membandingkan hasil (kinerja) yang dirasakan dibandingkan dengan harapannya. Menurut Kotler (2007) indikator kepuasan atau kepuasan pengkonsumsi dipengaruhi oleh hal-hal berikut:

a. Performan produk atau jasa, performan dan keunggulan suatu produk atau jasa sangatlah penting dalam mempengaruhi kepuasan pengguna produk tau jasa. 
b. Citra, citra atau reputasi perusahaan yang baik merupakan keunggulan bersaing yang mempengaruhi tingkat kepuasan pengguna produk atau jasa dari sudut positif. Terbentuknya citra adalah pada saat pengguna produk atau jasa memperoleh pengalaman yang menyenangkan dengan produk atau jasa.

c. Kinerja atau prestasi karyawan, kinerja prestasi karyawan tergantung pada bagaimana semua bagian organisasi bekerja sama dalam proses pemenuhan kepuasan.

\section{METODE PENELITIAN}

Penelitian ini dilakukan untuk menguji hipotesa yang diajukan dengan menggunakan metode penelitian yang telah dirancang sesuai dengan variabel-variabel yang akan diteliti yaitu kualitas pelayanan dan kepuasan nasabah terhadap swiching intention pada nasabah Bank Panin Kota Sungai Penuh agar mendapat hasil penelitian yang akurat. Dalam penelitian ini jenis data yang digunakan adalah data primer dan data sekunder. Data primer merupakan data penelitian yang diperoleh secara langsung dari sumber asli (tidak melalui perantara). Data primer secara khusus dikumpulkan oleh peneliti untuk menjawab penelitian. Data sekunder merupakan sumber data yang diperoleh dengan cara membaca, mempelajari dan memahami melalui media lain yang bersumber dari literatur, buku-buku, serta dokumen perusahaan. Data yang digunakan dalam penelitian ini adalah data primer dan data sekunder dimana data primer didata yang didapat dari tempat peneltian yaitu nasabah Bank Panin Kota Sungai Penuh. Data sekunder didapat dari kantor Bank Panin Kota Sungai Penuh untuk jumlah nasabah yang terdapat di Bank Panin Kota Sungai Penuh.

\section{Teknik Pengumpulan Data}

Teknik pengumpulan data yang digunakan dalam penelitian ini berupa studi keputusan (library research) yakni dengan pengambilan data yang dilakukan dengan membaca buku- buku, literatur-literatur serta tulisan ilmiah yang berkaitan dengan masalah yang dibahas. Penelitian lapangan (Field Research) yaitu pengumpulan data untuk memperoleh data primer dengan cara melakukan penelitian langsung di lapangan yaitu langsung kepada nasabah Bank Panin Kota Sungai Penuh.

\section{Metode Analisis Data}

Penelitian yang dilakukan ini dapat digolongkan sebagai penelitian yang menggunakan metode analisis deskriptif kuantitatif dan deskriptif kualitatif. Metode analisis deskriptif kuantitatif yakni analisa yang berbentuk angka-angka dalam hal ini dipakai analisis statistik. Analisa statistik adalah suatu metode guna memperoleh, mengolah dan menyajikan, menganalisa serta menginterprestasikan data yang berwujud angka-angka. Sedangkan metode analisis deskriptif kualitatif merupakan bentuk analisa dengan kata-kata bukan berbentuk angka melainkan berbentuk analisa secara penalaran bersumber dari penelitian terdahulu dan literatur-literatur yang relevan (Adisetiawan, 2013)

\section{Alat Analisis Data}

Alat analisis data dilaksanakan dengan melakukan perhitungan-perhitungan yang relevan terhadap masalah yang diteliti. Untuk mengolah data yang telah dikumpulkan dari hasil penelitian, menggunakan metode sebagai berikut: (Adisetiawan, 2016)

1. Regresi Linier Berganda`

Analisis kuantitatif dilakukan dengan menggunakan statistik untuk data yang memerlukan pengukuran.

Analisis kuantitatif bertujuan untuk mengetahui pengaruh variabel independen terhadap variabel dependen. Penelitian ini analisis statistik menggunakan Analisis Regresi Berganda: $Y=\alpha+\beta 1 X 1+$ $\beta 2 \mathrm{X} 2+\beta 2 \mathrm{X} 3+e$

2. Koefisien Determinasi (KD)

3. Koefisien determinasi (R2) pada intinya mengukur seberapa jauh kemampuan model dalam menerangkan variasi variabel independen. Nilai koefisien determinasi adalah antara nol dan satu.

\section{Uji Hipotesis}

\section{a. Uji F}


Uji pengaruh simultan digunakan untuk mengetahui apakah variabel independen secara simultan mempengaruhi variabel independen (Ghozali, 2006).

b. Uji t

Untuk mengetahui pengaruh antara variabel-variabel yang digunakan itu berarti (signifikan) atau tidak.

Untuk menguji keberartiannya itu melalui hipotesa, dimana uji ini menggunakan rumus

(Sumodiningrat, 2007).

\section{HASIL DAN PEMBAHASAN}

Perhitungan yang menggunakan metode Regresi Linier Berganda dan Koefisien Determinasi (KD) uji $\mathrm{F}$ dan uji t dalam pengaruh kualitas pelayanan dan kepuasan nasabah terhadap switching intention pada Nasabah Bank Panin Kota Sungai Penuh sebagai berikut :

\section{Tabel 1}

Analisis Regresi Linear Berganda

\begin{tabular}{|c|c|c|c|c|c|c|c|}
\hline \multirow{2}{*}{ Model } & \multicolumn{2}{|c|}{ Unstandardized Coefficients } & \multirow{2}{*}{$\frac{\text { Standardized Coefficients }}{\text { Beta }}$} & \multirow{2}{*}{$\mathrm{t}$} & \multirow{2}{*}{ Sig. } & \multicolumn{2}{|c|}{ Collinearity Statistics } \\
\hline & $\mathrm{B}$ & Std. Error & & & & Tolerance & VIF \\
\hline (Constant) & 1,235 & ,771 & & 1,601 & ,116 & & \\
\hline XI &,- 017 & ,010 &,- 018 & $-1,760$ & 085 & ,788 & 1,269 \\
\hline $\mathrm{X} 2$ & 1,882 & ,019 & 1,006 & 97,080 & .000 & ,788 & 1.269 \\
\hline
\end{tabular}

Fhitung 5880,518 R-squaren 0,998

Sumber: data olahan

Tabel 1 diketahui hasil perhitungan uji t kualitas pelayanan (XI) terhadap switching intention (Y) diperoleh persamaan garis regresi adalah $\mathrm{Y}=1,601-1,760(\mathrm{XI})$. Hal ini dapat diartikan bahwa besar pengaruh variabel kualitas pelayanan terhadap switching intention adalah diperoleh tabel sebesar 2,00958 maka diperoleh thitung $(-1,760)<$ tabel $(2,00958)$., karena thitung lebih kecil dari tabel ini berarti hubungan pengaruh kualitas pelayanan terhadap switching intention pada nasabah Bank Panin Kota Sungai Penuh periode 201 adalah negatif signifikan atau dapat diartikan tidak berpengaruh. Artinya semakin rendah kualitas pelayanan, maka ada kencenderungan semakin tinggi switching intention pada nasabah Bank Panin Kota Sungai Penuh, yang dikarenakan oleh pelayanan yang diberikan oleh Bank Panin Kota Sungai Penuh tidak sesuai dengan harapan yang diinginkan oleh nasabah Bank Panin Kota Sunga Penuh.

Berdasarkan Tabel 1 diketahui hasil perhitungan uji t kualitas pelayanan (XI) terhadap switching intention (Y) diperoleh persamaan garis regresi adalah $\mathrm{Y}=1,601+97,080(\mathrm{X} 2)$. Hal ini dapat diartikan bahwa besar pengaruh variabel kepuasan nasabah terhadap switching intention adalah diperoleh tabel sebesar 2,00958 maka diperoleh thitung $(97,080)>$ ttabel $(2,00958)$, karena thitung lebih besar dari tabel, ini berarti hubungan pengaruh kepuasan nasabah terhadap switching intention pada nasabah Bank Panin Kota Sungai Penuh periode 2016 adalah positif signifikan atau dapat diartikan berpengaruh. Dengan arti semakin tinggi kepuasan nasabah (X2), maka semakin tinggi swtiching intention (Y). Ada beragam alasan mengapa pelanggan meskipun sangat puas tetap berpindah ke perusahaan lain, yaitu adanya kualitas produk/jasa perusahaan atau tersedianya daya tarik baru yang ditawarkan oleh pesaing perusahaan. Dalam penelitian ini semakin tinggi kepuasan nasabah maka semakin tinggi pula swiching intention yang dikarenakan oleh produk/jasa yang disediakan oleh pesaing Bank Panin lebih murah dan menguntungkan bagi nasabah seperti setoran pembukaan rekening yang murah, biaya administrasi murah, biaya transfer ke bank lain murah, transfer ke sesama Bank tidak dikenakan biaya.

Tabel 1 di atas didapat hasil uji $\mathrm{F}$ tersebut diatas hasil olahan, bahwa didapat Ftabel dengan tingkat signifikan $\alpha=0,05$ dan didapat nilai Fhitung lebih besar dari Ftabel yang dibuktikan dengan nilai Fhitung 5880,518 dan nilai Ftabel 3,200 maka diperoleh persamaan Fhitung (5880,518) > Ftabel (3,200), maka Ho ditolak dan Ha diterima. Jadi dari penelitian ini didapat disimpulkan bahwa kualitas pelayanan dan kepuasan nasabah secara bersama-sama berpengaruh positif signifikan terhadap switching intention pada nasabah Bank Panin Kota Sungai Penuh periode tahun 2016. Artinya semakin tinggi kualitas pelayanan dan kepuasan nasabah semakin tinggi pula switching intention pada nasabah Bank Panin Kota Sungai Penuh 


\section{Edia Satria}

periode 2016. Artinya semakin tinggi tingkat kualitas pelayanan dan kepuasan yang dirasakan nasabah, maka semakin tinggi pula tingkat niat pelanggan (nasabah) untuk beralih. Pengkuadratan dari koefisien 0,998 R-Square dapat disebut koefisien determinasi yang di dalam hal ini berarti 99,8\% kontribusi variabel kualitas pelayanan dan Kepuasanan nasabah terhadap switching intention, sedangkan sisanya $4 \%$ dapat dijelaskan oleh sebab-sebab lain.

\section{SIMPULAN}

Kualitas pelayanan berpengaruh negatif signifikan dimana didapat thitung lebih kecil dari tabel dan juga signifikan besar dari 0,05 (thitung $(-0,017)<$ tabel $(2,00958)$ dan signifikan $>0,05(0,085>0,05)$. Bedasarkan hal tersebut dapat diartikan bahwa kualitas pelayanan tidak berpengaruh terhadap switching intention pada nasabah Bank Panin Kota Sungai Penuh. Kepuasan nasabah berpengaruh positif signifikan dimana didapat thitung lebih besar dari ttabel dan juga signifikan kecil dari 0,05 (thitung $(97,080)>$ ttabel $(2,00958)$ dan signifikan $<0,05(0,000<0,05)$. Bedasarkan hal tersebut dapat diartikan bahwa kepuasan nasabah berpengaruh terhadap switching intention pada nasabah Bank Panin Kota Sungai Penuh. Kualitas pelayanan dan kepuasan nasabah secara simultan berpengaruh positif signifikan terhadap switching intention yang ditandai dengan Fhitung lebih besar dari Ftabel (Fhitung (5880,518) > Ftabel 3,200). Berdasarkan hal tersebut dapat diartikan secara simultan kualitas pelayanan dan kepuasan nasabah berpengaruh terhadap switching intention pada nasabah Bank Panin Kota Sungai Penuh.

\section{DAFTAR PUSTAKA}

Adisetiawan, R., 2013, Kajian Persepsi Pemilik Usaha Kecil dan Menengah (UKM) Terhadap Laporan Keuangan, Jurnal Ilmiah Universitas Batanghari Jambi, 13(4), 162-173

Adisetiawan, R., 2017, Performance Mahasiswa Fakultas Ekonomi Universitas Batanghari, Jurnal Ilmiah Universitas Batanghari, 14(3), 1-10

Alhudhori, M., 2015, Pengaruh Kualitas Pelayanan Mutu Akademik terhadap Kepuasan Mahasisa Program Studi S2 Magister Manajemen Fakultas Ekonomi Universitas Batanghari Jambi, Jurnal Ilmiah Universitas Batanghari Jambi, 15(2), 99-107

Nelloh dan Liam, 2011. Pengaruh Switching Cost Terhadap Word Of Mouth Dengan Switching Intention Sebagai Variabel Intervening Pada Pengguna Jasa Layanan Kurir Jne Di Samarinda. FORUM EKONOMI: Jurnal Ekonomi, Manajemen dan Akuntansi, 18(2), 2016.

Clemes, Gan, \& Zhen, 2007, Indikator Switching Inetention, Jurnal Manajemen dan Akuntansi, Bilang Ramdhan. Semarang.

Kotler and Keller, 2007, Pengaruh Kualitas Layanan dan Kepuasan Pelanggan Terhadap Switching Intention Pengguna Jasa Rumah Kost di Wilayah Kecamatan Sumbersari Jember. 